\title{
1,25-Dihydroxyvitamin D3 prevents bone loss of the secondary spongiosa in arthritic rats by an increase of bone formation and mineralization and inhibition of bone resorption
}

Peter Oelzner ${ }^{1 *}$, Peter K Petrow ${ }^{2}$, Gunter Wolf ${ }^{1}$ and Rolf Bräuer ${ }^{2}$

\begin{abstract}
Background: Active vitamin D metabolites have been shown to have protective effects in experimental arthritis especially when used as preventive treatment. However, because the direct effects of 1,25-dihydroxyvitamin D3 $\left(1,25(\mathrm{OH})_{2} \mathrm{D}_{3}\right)$ on bone formation and resorption are very complex, the net effect of $1,25(\mathrm{OH})_{2} \mathrm{D}_{3}$ on histomorphometric parameters of bone turnover and mineralisation should be investigated. Therefore, we examined the influence of $1,25(\mathrm{OH})_{2} \mathrm{D}_{3}$ therapy on arthritis-induced alterations of periarticular and axial bone as well as disease activity, inflammation and joint destruction in antigen-induced arthritis (AIA) of the rat.

Methods: AIA was induced in 20 eight-week-old female Wistar rats. 10 rats without arthritis were used as healthy controls. AlA rats received $1,25(\mathrm{OH})_{2} \mathrm{D}_{3}(0.2 \mu \mathrm{g} / \mathrm{kg} /$ day, i.p., $\mathrm{n}=10)$ or vehicle $(\mathrm{n}=10)$ at regular intervals for 28 consecutive days beginning 3 days before arthritis induction. Bone structure of the secondary spongiosa of the periarticular and axial bone was analyzed using histomorphometry. Parameters of mineralization were investigated using tetracycline labelling. Clinical disease activity, inflammation and joint destruction were measured by joint swelling and histological investigation, respectively.
\end{abstract}

Results: AlA led to significant periarticular bone loss. $1,25(\mathrm{OH})_{2} \mathrm{D}_{3}$ treatment resulted in a highly significant increase in trabecular bone volume and bone formation rate in comparison to both vehicle-treated AIA and healthy controls at periarticular ( $p<0.01$ and $p<0.001$, respectively) and axial bone $(p<0.001$ and $p<0.001$, respectively). In addition, bone resorption was reduced by $1,25(\mathrm{OH})_{2} \mathrm{D}_{3}$ at the axial bone $(\mathrm{p}<0.05 \mathrm{vs}$. vehicle-treated $\mathrm{Al} A)$. Joint swelling as well as histological signs of inflammation and joint destruction were not influenced by $1,25(\mathrm{OH})_{2} \mathrm{D}_{3}$.

Conclusions: The results of the study indicate a marked osteoanabolic effect of $1,25(\mathrm{OH})_{2} \mathrm{D}_{3}$ presumably due to a substantial increase in mineralization. Thus, $1,25(\mathrm{OH})_{2} \mathrm{D}_{3}$ may be an effective osteoanabolic treatment principle to antagonize the inflammation-associated suppression of bone formation in rheumatoid arthritis.

Keywords: Arthritis models, Bone, Vitamin D hormone

\footnotetext{
* Correspondence: peter.oelzner@med.uni-jena.de

'Department of Internal Medicine III, University Hospital of Jena, Erlanger

Allee 101, 07740 Jena, Germany

Full list of author information is available at the end of the article
} 


\section{Background}

Rheumatoid arthritis (RA) is characterized by early periarticular demineralization followed by periarticular bone destruction and often complicated by systemic bone loss resulting in fractures [1-3]. Both increased osteoclastic bone resorption due to an imbalance between the production of receptor activator of NFKB ligand (RANKL) which stimulates bone resorption and its decoy receptor osteoprotegerin (OPG) [4-8] and decreased bone formation and repair mediated by increased production of wnt inhibitors [8-11] contribute to bone destruction and systemic osteoporosis. Furthermore, the finding that the knockout of nuclear factor erythroid 2-related factor 2 (Nrf2), a transcription factor that maintains the cellular defence against oxidative stress, in mice with antibodyinduced arthritis was associated not only with an increase in cartilage destruction but also with a high number of spontaneous fractures underlines the importance of reactive oxygen species for bone damage in arthritis models [12]. Based on these pathogenetic mechanisms, which are often only incompletely suppressed by immunosuppressive therapy, adjuvant treatment of RA with substances, that are potentially able to prevent bone loss, is of particular interest. The vitamin $\mathrm{D}$ hormone 1,25-dihydroxycholecalciferol $\left(1,25(\mathrm{OH})_{2} \mathrm{D}_{3}\right)$ has been shown to induce osteoblast differentiation [13-15]. Furthermore, $1,25(\mathrm{OH})_{2} \mathrm{D}_{3}$ acts as an antiinflammatory substance by marked influences on $\mathrm{T}$ cell differentiation with a suppression of Th1 and Th17 cells and induction of differentiation into Th2 und regulatory T cells as well as by suppression of costimulation receptors on antigenpresenting cells, inhibition of differentiation of dendritic cells and inhibition of $\mathrm{NF}_{\kappa} \mathrm{B}$ activation, p38 activation and cytokine production in monocytes/macrophages and suppression of angiogenesis [16-23]. RA is often associated with vitamin $\mathrm{D}$ deficiency and serum levels of $1,25(\mathrm{OH})_{2} \mathrm{D}_{3}$ have been shown to decrease in patients with high disease activity $[24,25]$. Therefore, $1,25(\mathrm{OH})_{2} \mathrm{D}_{3}$ may have a beneficial effect on both bone metabolism and inflammation in RA and animal models of this disease. A very detailed and comprehensive analysis regarding immunological processes, cytokines involved in bone resorption and bone turnover was performed in vitamin $\mathrm{D}$ receptor (VDR) knockout mice with spontaneously developing arthritis [20]. Furthermore, a preventive or protective effect of the treatment with $1,25(\mathrm{OH})_{2} \mathrm{D}_{3}$ or with other active vitamin $\mathrm{D}$ metabolites in experimental arthritis (animal models of RA) has been shown [26-34]. However, most of the cited studies focused on incidence, severity and duration of arthritis [29-33] including detailed investigation of immunological mechanisms of arthritis [34] and an analysis of bone was not performed or bone turnover was not measured using histomorphometry. A detailed investigation of the effect of $1,25(\mathrm{OH})_{2} \mathrm{D}_{3}$ on bone turnover is necessary because the direct effects of $1,25(\mathrm{OH})_{2} \mathrm{D}_{3}$ on bone include the expression of RANKL which may result in increased bone resorption [35], whereas bone resorption could be suppressed indirectly by inhibition of inflammation [20]. To determine the net effect of $1,25(\mathrm{OH})_{2} \mathrm{D}_{3}$ on bone and inflammation, we investigated the influence of $1,25(\mathrm{OH})_{2} \mathrm{D}_{3}$ on histomorphometric parameters of bone turnover and mineralisation at periarticular and axial bone as well as on inflammatory disease activity in antigen-induced arthritis (AIA) of the rat, a T cell-dependent model of RA [36,37].

\section{Methods}

\section{Arthritis induction}

Eight-week-old female Wistar rats (Central Animal Research Facility, University Hospital, Jena, Germany) maintained under standardized conditions were subjected to a $12 \mathrm{~h} / 12 \mathrm{~h}$ light/darkness cycle and fed with pellet food (Altromin, No 1326, Lage, Germany) and water ad libitum.

Because of the complex regulation of vitamin D metabolism including both a strongly regulated renal synthesis of $1,25(\mathrm{OH})_{2} \mathrm{D}_{3}$ and a substrate dependent 1,25 $(\mathrm{OH})_{2} \mathrm{D}_{3}$ synthesis in osteoblasts and immune cells [13-15,19], 1,25(OH) ${ }_{2} \mathrm{D}_{3}$ effects could also be influenced by vitamin $\mathrm{D}$ intake. To keep the influence of vitamin $\mathrm{D}$ intake on the results of our experiment constant, a diet containing a physiological and standardized concentration of vitamin D was started in arthritic animals before arthritis induction and also in healthy animals.

The diet contained $0.9 \%$ calcium $(0.9 \mathrm{~g}$ calcium $/ 100 \mathrm{~g})$, $0.7 \%$ phosphorus $(0.7 \mathrm{~g}$ phosphorus/100 g) and $600 \mathrm{IU}$ vitamin D3 per $\mathrm{kg}$. With respect to vitamin D3 and calcium content this is a conventional diet comparable to those used by Vieth et al. [38].

The animals were subcutaneously immunized with $0.5 \mathrm{mg}$ of methylated bovine serum albumin (mBSA, Sigma, Deisenhofen, Germany) in $0.5 \mathrm{ml}$ of saline and emulsified in $0.5 \mathrm{ml}$ of complete Freund's adjuvant (Sigma), containing $2 \mathrm{mg} / \mathrm{ml}$ of heat-killed Mycobacterium tuberculosis strain H37RA (Difco, Detroit, MI, USA) 21 and 14 days before AIA induction.

Arthritis was elicited by injecting $0.5 \mathrm{mg} \mathrm{mBSA}$ in $50 \mu \mathrm{l}$ sterile phosphate-buffered saline (PBS) into the right knee joint cavity. The same volume of PBS was injected into the left knee as an intra-individual control. Ethical guidelines for experimental investigations in animals were used [39]. All procedures complied with the regulations of the Thuringian Commission for Animal Protection. The approval of our local ethics committee was obtained for our study. 


\section{Drug administration}

Rats with AIA were divided into 2 groups to receive intraperitoneal injections before and after AIA induction according to the following regimens:

Group 1: $1,25(\mathrm{OH})_{2} \mathrm{D}_{3}$ (Calcijex, Abbott, Chicago USA), $0.2 \mu \mathrm{g} / \mathrm{kg}$ beginning three days before arthritis induction up to day 15 after arthritis induction every day and after day 15 every other day. The cumulative dose of $1,25(\mathrm{OH})_{2} \mathrm{D}_{3}$ in this group was $6.5 \mu \mathrm{g} / \mathrm{kg}$.

Group 2: $50 \mu \mathrm{l}$ of solvent for $1,25(\mathrm{OH})_{2} \mathrm{D}_{3}$ (vehicle) beginning three days before arthritis induction up to day 15 after arthritis induction every day and after day 15 every other day (untreated AIA; $\mathrm{n}=10$ ). The solvent contains $20.4 \mathrm{mg} / \mathrm{ml}$ polysorbate and $2.5 \mathrm{mg} / \mathrm{ml}$ sodium ascorbate.

The time point to start $1,25(\mathrm{OH})_{2} \mathrm{D}_{3}$ application in our experiment three days before AIA induction was determined by both using more a therapeutic than a prophylactic regimen of $1,25(\mathrm{OH})_{2} \mathrm{D}_{3}$ administration and to achieve a complete treatment effect in the early acute phase of AIA. At this time point the immunologic changes characteristic for AIA were established [36,37]. On the other hand, regarding the time course of AIA with an early acute phase with high disease activity and a longer chronic phase with lower disease activity we targeted a complete treatment effect in the early acute phase of the arthritis.

Additionally, ten healthy animals (without immunization and AIA) were used as healthy controls.

The serum levels of vitamin D were not measured throughout the experiment.

\section{Assessment of arthritis}

Arthritis was monitored by measuring the mediolateral joint diameter using a vernier caliper [40]. Swelling was expressed as the difference in $\mathrm{mm}$ between the right arthritic and the left reference joint at the days 3, 7, 14, 22 and 28 after arthritis induction.

\section{Preparation of bones for histomorphometric and histopathologic analysis}

All 20 arthritic rats, as well as 10 healthy age-matched controls, were sacrificed on day 28 after AIA induction. Both the right tibia head of the arthritic knee joint and the third lumbar vertebra were removed and used for histomorphometric analysis. After preparation, the bones were fixed in acetone for 24 hours and embedded using the embedding system Technovit 9100 NEU (HeraeusKulzer, Wehrheim, Germany) for mineralized tissue. In principal, the system is based on chemical polymerization employing a catalytic system consisting of peroxide and amine without oxygen. A Polycut S-Special Microtome was used to cut $5 \mu \mathrm{m}$ thick sections (Jung/Leica, Heidelberg, Germany). Trichrome Masson/Goldner staining was performed to differentiate mineralized bone and osteoid [41]. In addition, Giemsa staining was performed to allow distinction of the cellular components of bone tissue.

\section{Histopathologic assessment of inflammation and joint destruction}

Cross sections from knee joints were stained with hematoxylin and eosin (HE) and were evaluated using a photomicroscope (Axioskop 2, Carl Zeiss, Jena, Germany). To analyze the inflammatory and destructive activity of arthritis, knee joint sections were examined in a blind fashion using a semiquantitative score $(0=$ no, $1=$ mild, 2 = moderate, 3 = severe alterations) for the extent of acute (quantity of fibrin exudation and relative number and density of granulocytes in the synovial membrane and in joint space) and chronic inflammatory changes (relative number and density of infiltrating mononuclear leukocytes in the synovial membrane, degree of synovial hyperplasia, and extent of fibrosis in the synovial tissues). To asses the degree of cartilage destruction a score from 0 to 4 was used $(0=$ no destruction, $1=$ unequivocal erosions of less than $10 \%$ of cartilage and bone cross sections, $2=$ erosion of $10-25 \%, 3=$ erosion of $25-50 \%, 4=$ erosion of more than $50 \%$ of cartilage and bone cross sections) [40,42]. Additional histological sections were stained with safranin
A

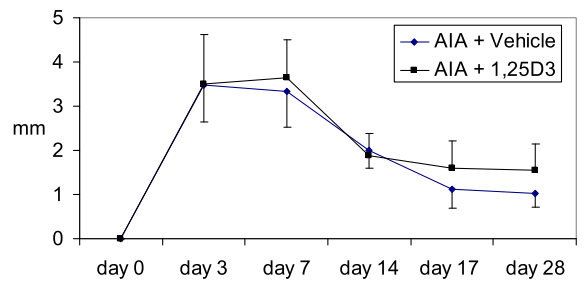

B

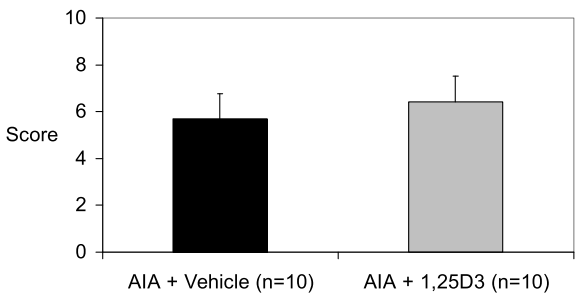

Figure 1 Knee joint swelling (A) and histopathologic score (sum of the semiquantitative scores expressed as points for both, inflammation and joint destruction, see Methods for details) of arthritis on day $\mathbf{2 8}$ after AIA induction (B). The knee joint swelling measured as difference between right and left joint during the time course of AIA as well as the histopathologic signs of inflammation and joint destruction were not influenced by $1,25(\mathrm{OH})_{2} \mathrm{D}_{3}$ therapy. 
A

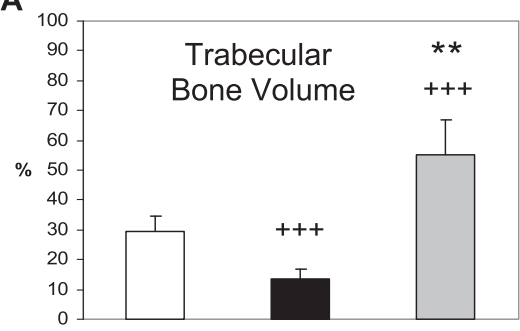

B

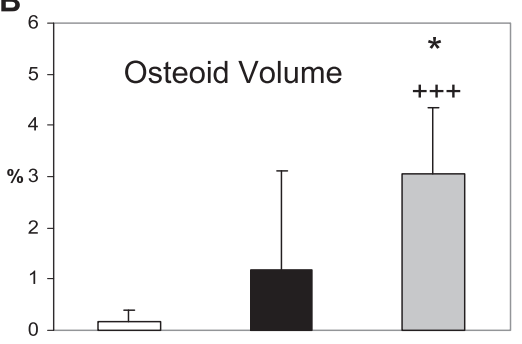

C

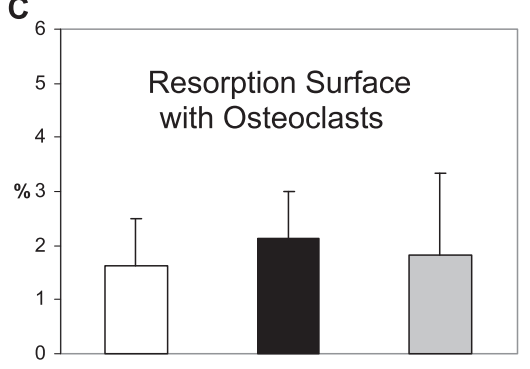

$\mathbf{D}_{70}$

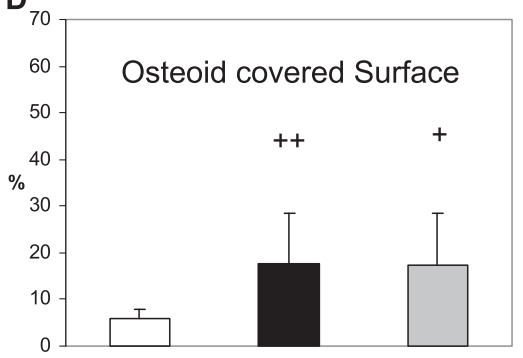

E

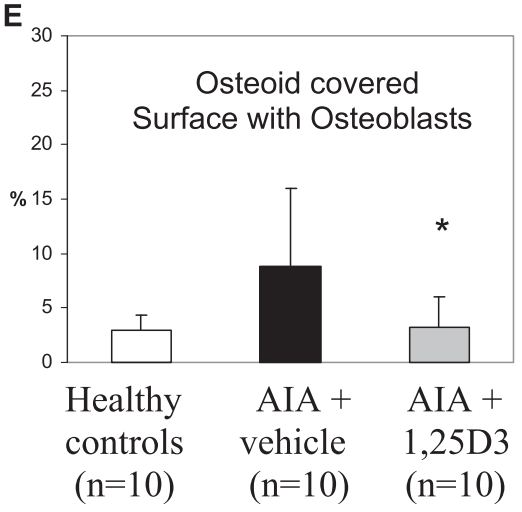

Figure 2 Influence of $1,25(\mathrm{OH})_{2} \mathrm{D}_{3}$ therapy on trabecular bone volume, osteoid volume and cellular bone turnover parameters (secondary spongiosa of the right tibia head - arthritic joint) in AIA of the rat. In comparison to healthy controls, vehicle-treated AIA (AIA + vehicle) was associated with a highly significant decrease of trabecular bone volume (A), a significant increase in osteoid-covered surface (D) and a numerical increase in osteoid volume (B) and osteoid-covered surface with osteoblasts $(\mathbf{E}) .1,25(\mathrm{OH})_{2} \mathrm{D}_{3}$ therapy completely inhibited AIA-induced bone loss and resulted in a significant increase of trabecular bone volume (A) and osteoid volume (B) in comparison to vehicle-treated AIA and healthy controls. Osteoid-covered surface with osteoblasts was reduced by $1,25(\mathrm{OH})_{2} \mathrm{D}_{3}$ treatment to values of healthy controls $(\mathbf{E})$. Osteoid-covered surface remained increased in comparison to healthy animals (D). Resorption surface with osteoclasts was not significantly influenced by AIA and by 1,25(OH)2D3 therapy (C). ${ }^{* *} p<0.01 ;{ }^{*} p<0.05$ vs. AlA + vehicle; $+++p<0.001 ;++p<0.01 ;+$ $p<0.05$ vs. healthy controls.

$\mathrm{O}$ to determine the loss of proteoglycan in the cartilage matrix, using scoring system as used for the evaluation of inflammatory features.

\section{Histomorphometric analysis of bone structure}

Histomorphometric analysis of the bone structure was performend in the secondary spongiosa consisting of lamellar bone which represents homogeneous bone tissue. Secondary spongiosa is beginning at a distance of $1,25 \mathrm{~mm}$ from growth plate and was differentiated from primary spongiosa by means of morphological criteria (absence of cartilage cores) [43,44].

In the secondary spongiosa trabecular bone volume and histomorphometric parameters of bone formation and bone resorption were evaluated by standard histomorphometry $[41,45,46]$. For tetracycline labeling, all animals received intraperitoneal injections of $45 \mathrm{mg} / \mathrm{kg}$ tetracycline (Supramycine; Grünenthal, Stolberg, Germany) at a volume of $1 \mathrm{ml}$ PBS on day 22 and 25 after AIA induction.

Single-labeled and double-labeled surface as well as the mean distance between double labels were measured at uncoulored bone sclices of the same region used for histomorphometry by fluorescence microscopy (Axioplan, Carl Zeiss, Jena, Germany). Based on the measurements, parameters of bone formation and mineralization were calculated [47].

The measured parameters of standard histomorphometry of the trabecular bone of the secondary spongiosa are listed.

A) Bone volume

1) Trabecular bone volume in relationship to tissue volume (\%)

2) Osteoid volume in relationship to bone volume (\%). 
B) Bone resorption

Resorption surface with osteoclasts in relation to whole bone surface (\%) [i.e. levels of osteoclastic bone resorption].

C) Bone formation

1) Osteoid-covered surface in relation to whole bone surface (\%) [i.e. bone surface covered with non-mineralized, newly formed bone matrix].

2) Osteoid-covered surface with osteoblasts in relation to whole bone surface (\%) [i.e. levels of cellular bone formation].

3) Mineralizing surface.

MS/OS $(\%)=\frac{\text { single-labeled surface }+ \text { double-labeled surface }}{2}$

4) Mineral apposition rate (MAR), calculated by mean distance between double labels divided by the interval labeling time ( 3 days) $(\mu \mathrm{m} /$ day)

5) Bone formation rate (BFR/BS), calculated as $\mathrm{MAR} \times \mathrm{MS} / \mathrm{BS}(\mu \mathrm{m} 3 / \mu \mathrm{m} 2 /$ day $\times 10-2)$.

\section{Statistical analysis}

Data were presented as means \pm standard deviation. The data were analysed statistically using the SPSS for Windows Statistical Programme [48]. Data were subjected to the non-parametric Kruskall-Wallis-analysis and, subsequently to the non-parametric MannWhitney U-test. Differences of $\mathrm{p}<0.05$ were considered significant.

\section{Results}

Influence of $1,25(\mathrm{OH})_{2} \mathrm{D}_{3}$ therapy on arthritis severity

After arthritis induction rats developed rapid inflammation indicated by the acute joint swelling with a maximum between day 3 and 7 (Figure 1A). The clinical disease activity measured as joint swelling during the course of arthritis as well as the histological signs of inflammation and joint destruction as sum of the semiquantitative scores expressed as points for both, inflammation and joint destruction on day 28 after AIA induction were not influenced by $1,25(\mathrm{OH})_{2} \mathrm{D}_{3}$ treatment (Figure $1 \mathrm{~A}$ and $1 \mathrm{~B}$ ).

\section{Influence of AIA on periarticular and axial bone (secondary spongiosa)}

AIA resulted in a highly significant decrease in trabecular bone volume of the secondary spongiosa of the right tibia head (periarticular bone of the arthritic joint; $\mathrm{p}<0.001$, Figures $2 \mathrm{~A}$ and $3 \mathrm{~B}$ ). Arthritic animals were characterized by a numerical increase of resorption surface with osteoclasts (Figure 2C) and a significant increase of osteoid-covered surface and osteoid-covered surface with osteoblasts at periarticular bone $(\mathrm{p}<0.01$, Figure 2D,E). Mineralizing surface, mineral apposition rate and bone formation rate at the periarticular bone were not influenced by AIA (Figure 4A-C). In contrast, trabecular bone volume of the axial bone (third lumbar vertebra) was unaffected by AIA (Figure 5A). Resorption surface with osteoclasts was numerically increased, osteoid-covered surface and osteoid-covered surface with osteoblasts at the axial bone were significantly increased in arthritic animals $(\mathrm{p}<0.05$, Figure $5 \mathrm{C}, \mathrm{D}, \mathrm{E})$. The parameters of bone formation measured by tetracycline labeling were not influenced by AIA at the axial bone (Figure 6A-C).

\section{Influence of treatment with $1,25(\mathrm{OH})_{2} \mathrm{D}_{3}$ on the secondary spongiosa of the right tibia head (periarticular bone)}

$1,25(\mathrm{OH})_{2} \mathrm{D}_{3}$ therapy led to a significant increase in trabecular bone volume (Figures $2 \mathrm{~A}$ and $3 \mathrm{C}$ ) not only in comparison to vehicle-treated AIA $(\mathrm{p}<0.01)$ but also compared to healthy animals $(\mathrm{p}<0.01)$. Furthermore, a significant increase in osteoid volume in comparison to vehicle-treated AIA $(\mathrm{p}<0.05)$ and to healthy animals $(\mathrm{p}<0.001)$ was observed with $1,25(\mathrm{OH})_{2} \mathrm{D}_{3}$ therapy (Figure 2B). Resorption surface with osteoclasts and osteoid-covered-surface were not influenced by $1,25(\mathrm{OH})_{2} \mathrm{D}_{3}$ as compared to vehicle-treated AIA (Figure $2 \mathrm{C}$ and 2D). Accordingly, osteoid-covered surface in animals receiving $1,25(\mathrm{OH})_{2} \mathrm{D}_{3}$ was significantly

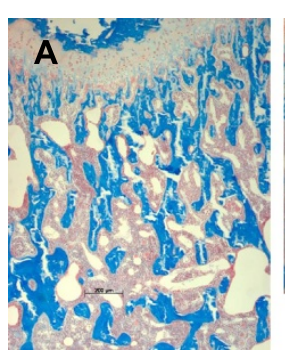

Healthy controls

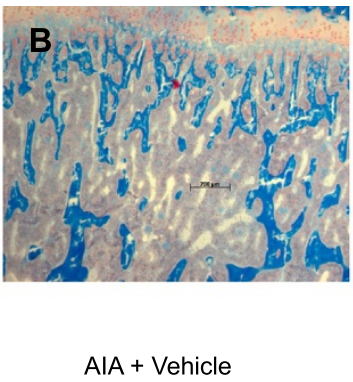

AIA + Vehicle

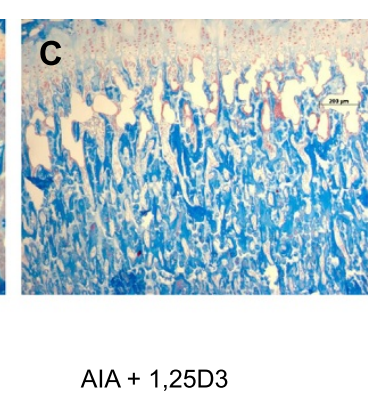

Figure 3 Assessment of bone histology, secondary spongiosa of the right tibia head (representative Masson/Goldner stained sections). In comparison to healthy controls (A), vehicle-treated AlA resulted in a significant bone loss in secondary spongiosa (B). Therapy with $0.2 \mu \mathrm{g} / \mathrm{kg}$ $1,25(\mathrm{OH})_{2} \mathrm{D}_{3}$ prevented AlA-induced bone loss completely and resulted in a highly significant increase in trabecular bone volume in comparison to both vehicle-treated AIA and healthy controls (C) 


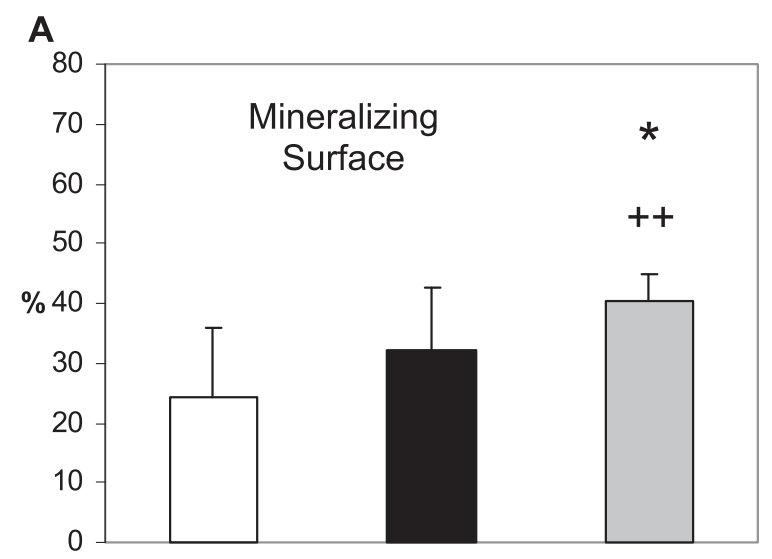

B
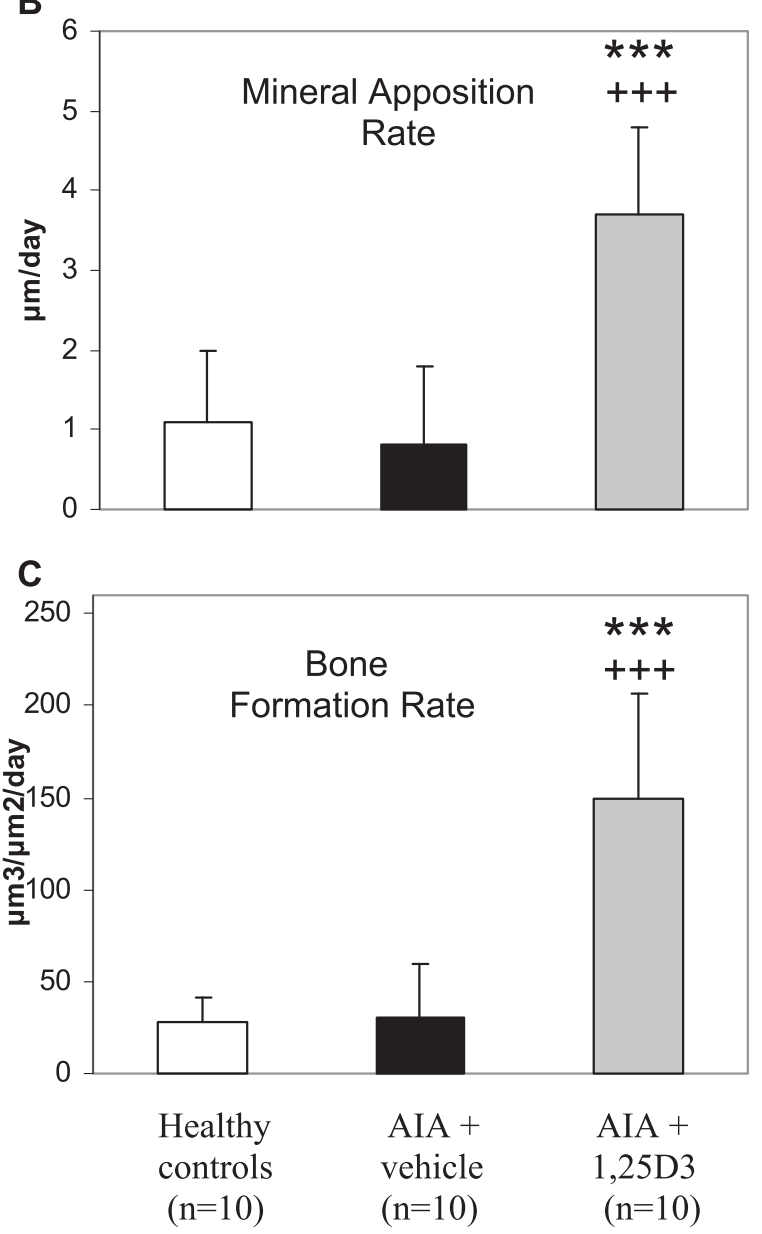

Figure 4 Influence of $1,25(\mathrm{OH})_{2} \mathrm{D}_{3}$ therapy on parameters of bone formation measured by tetracylin labeling (secondary spongiosa of the right tibia head - arthritic joint) in AIA of the rat. Mineralizing surface (A), mineral apposition rate (B) and bone formation rate $(\mathbf{C})$ were unaffected by AIA. Treatment with $1,25(\mathrm{OH})_{2} \mathrm{D}_{3}$ resulted in a highly significant increase of mineral apposition rate and bone formation rate and a significant increase in mineralizing surface compared with vehicle-treated AIA and healthy controls. ${ }^{* * *} \mathrm{p}<0.001 ;{ }^{*} \mathrm{p}<0.05 \mathrm{vs}$. AlA + vehicle; +++ $p<0.001 ;++p<0.01$ vs. healthy controls. higher in comparison to healthy animals $(\mathrm{p}<0.05)$. In contrast to osteoid-covered surface, osteoid-covered surface with osteoblasts was significantly reduced by $1,25(\mathrm{OH})_{2} \mathrm{D}_{3}$ therapy compared with vehicle-treated AIA $(p<0.05)$, resulting in a decrease of this parameter to the values of healthy animals (Figure 2E). Despite a decrease in osteoid-covered surface with osteoblasts, both mineralizing surface and mineral apposition rate were significantly increased by $1,25(\mathrm{OH})_{2} \mathrm{D}_{3}$ therapy in comparison to vehicle-treated AIA ( $p<0.05$ and $\mathrm{p}<$ 0.001 , respectively) and compared to healthy animals $(\mathrm{p}<0.01$ and $\mathrm{p}<0.001$, respectively, Figure $4 \mathrm{~A}$ and $4 \mathrm{~B})$. The increase of these both parameters of bone formation resulted in a highly significant increase of bone formation rate in $1,25(\mathrm{OH})_{2} \mathrm{D}_{3}$-treated rats in comparison to both vehicle-treated AIA and healthy animals $(\mathrm{p}<0.001$, Figure 4C).

Influence of treatment with $1,25(\mathrm{OH})_{2} \mathrm{D}_{3}$ on the secondary spongiosa of the third lumbar vertebra (axial bone)

According to the findings at the periarticular bone, both trabecular bone volume and osteoid volume were highly significant increased by $1,25(\mathrm{OH})_{2} \mathrm{D}_{3}$ treatment in comparison to vehicle-treated AIA and healthy animals $(\mathrm{p}<$ 0.001 , Figure $5 \mathrm{~A}$ and $5 \mathrm{~B}$ ). Both resorption surface with osteoclasts and osteoid-covered surface with osteoblasts were significantly reduced by $1,25(\mathrm{OH})_{2} \mathrm{D}_{3}$ therapy in comparison to vehicle-treated AIA $(p<0.05$, Figure $5 \mathrm{C}$ and $5 \mathrm{E}$ ) to levels according to those of healthy animals. Osteoid-covered surface remained numerically higher in comparison to healthy animals in $1,25(\mathrm{OH})_{2} \mathrm{D}_{3}$-treated rats (Figure 5D). Mineralizing surface and mineral apposition rate were significantly increased during 1,25 $(\mathrm{OH})_{2} \mathrm{D}_{3}$ therapy in comparison to vehicle-treated AIA $(\mathrm{p}<0.001)$ and compared to healthy animals $(\mathrm{p}<0.01$; Figure $6 \mathrm{~A}$ and $6 \mathrm{~B})$. Accordingly, $1,25(\mathrm{OH})_{2} \mathrm{D}_{3}$ treatment resulted in a highly significant increase in bone formation rate in comparison to both vehicle-treated AIA and healthy animals $(\mathrm{p}<0.001$, Figure $6 \mathrm{C})$.

\section{Discussion}

A suppressive effect of $1,25(\mathrm{OH})_{2} \mathrm{D}_{3}$ therapy on inflammation and joint destruction was not observed in our study. From the background of the $\mathrm{T}$ cell-dependence of AIA, this is surprising, because important immunomodulatory effects of $1,25(\mathrm{OH})_{2} \mathrm{D}_{3}$ are mediated by the modulation of $\mathrm{T}$ cell differentiation contributing to protective effects of $1,25(\mathrm{OH})_{2} \mathrm{D}_{3}$ in different $\mathrm{T}$ cellmediated diseases [16-19,23]. The most probable explanation for the missing anti-inflammatory effect of 1,25 $(\mathrm{OH})_{2} \mathrm{D}_{3}$ in the present study may be the relatively short $1,25(\mathrm{OH})_{2} \mathrm{D}_{3}$ administration period in the prearthritic phase of AIA beginning only on day 3 before arthritis induction. 

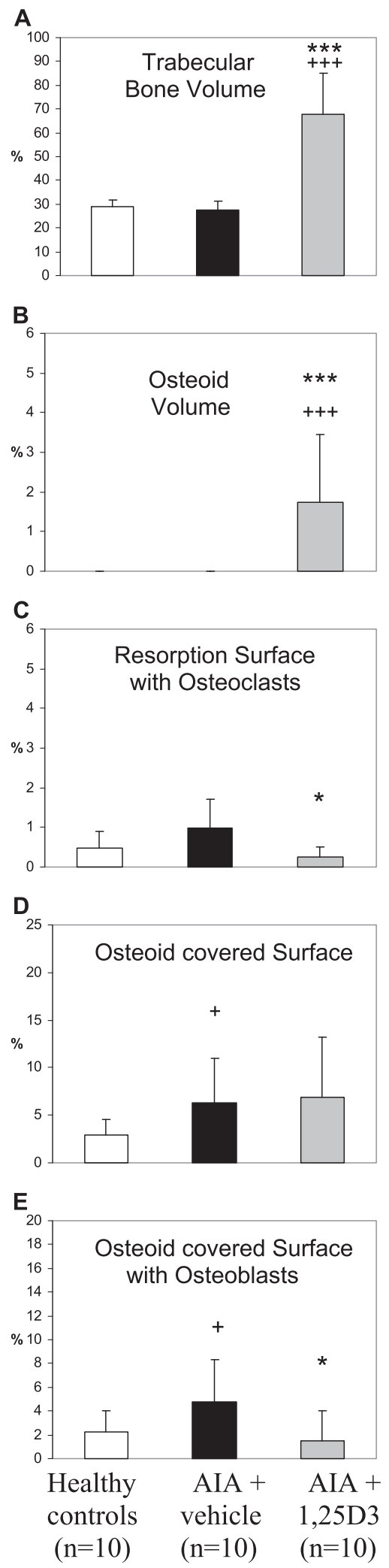

Figure 5 Influence of $1,25(\mathrm{OH})_{2} \mathrm{D}_{3}$ therapy on trabecular bone volume, osteoid volume and cellular bone turnover parameters (secondary spongiosa of the third lumbar vertebra) in AIA of the rat. Vehicle-treated AIA was associated with a significant increase of osteoid-covered surface and osteoid-covered surface with osteoblasts (D; E) and a numerical increase in resorption surface with osteoclasts (C) in comparison with healthy controls. Trabecular bone volume and osteoid volume at the axial bone remained unaffected by AIA (A; B). 1,25(OH) $)_{2} \mathrm{D}_{3}$ therapy led to a highly significant increase of trabecular bone volume (A) and osteoid volume (B) in comparison to vehicle-treated AIA and healthy controls and resulted furthermore in a significant decrease in resorption surface with osteoclasts (C) and osteoid-covered surface with osteoblasts (E) in comparison to vehicle-treated AIA and reduced these parameters to the values of healthy controls. ${ }^{* *} p<0.001 ;{ }^{*} p<0.05$ vs. AlA + vehicle; +++ $p<0.001 ;+p<0.05$ vs. healthy controls.

In contrast to our investigation, in studies with evidence for inhibitory effects of active vitamin D metabolites on incidence, severity and/or progression of arthritis in collageninduced arthritis (CIA) of rats [30,33] and mice [32] and in adjuvant arthritis of the rat [29] treatment was initiated prior to immunization or at the time point of immunization or the animals were treated over a longer period during the prearthritic phase, respectively. Due to the long time period between the two immunizations on day 21 an day 14 before arthritis induction and the first administration of $1,25(\mathrm{OH})$ ${ }_{2} \mathrm{D}_{3}$ in our study, it is probable that a substantial part of $\mathrm{T}$ cells has been differentiated into the proinflammatory Th17 and Th1 cells before $1,25(\mathrm{OH})_{2} \mathrm{D}_{3}$ application.

In contrast to the missing anti-inflammatory effect, we observed substantial effects of $1,25(\mathrm{OH})_{2} \mathrm{D}_{3}$ therapy on periarticular and axial bone.

The main finding of our study is the dramatic osteoanabolic effect of $1,25(\mathrm{OH})_{2} \mathrm{D}_{3}$ therapy resulting in an important increase in trabecular bone volume in comparison to untreated AIA rats and healthy controls at both periarticular and axial bone, despite the ineffectiveness of the treatment on the inflammation. Interestingly, the increase in parameters of bone formation and mineralization such as bone formation rate in $1,25(\mathrm{OH})_{2} \mathrm{D}_{3}$-treated AIA rats occurs despite a significant reduction of osteoid-covered surface with osteoblasts in comparison to untreated AIA indicating an increase of the capacity of the single osteoblast to form new bone due to treatment with active vitamin D hormone. Although the direct effects of $1,25(\mathrm{OH})$ ${ }_{2} \mathrm{D}_{3}$ on osteoblasts are dependent on the species examined, the time course of $1,25(\mathrm{OH})_{2} \mathrm{D}_{3}$ treatment and the differentiation state of osteoblasts, an osteoanabolic vitamin D receptor-mediated signaling in mature osteoblasts has been clearly shown in other studies $[14,15,49]$. Osteoanabolic effects of $1,25(\mathrm{OH})_{2} \mathrm{D}_{3}$ include an increase of the expression of genes involved in mineralization such as alkaline phosphatase and osteocalcin $[13,14,50,51]$. Although the findings on the effect of $1,25(\mathrm{OH})_{2} \mathrm{D}_{3}$ on mineralization are not consistent and dose-dependent 


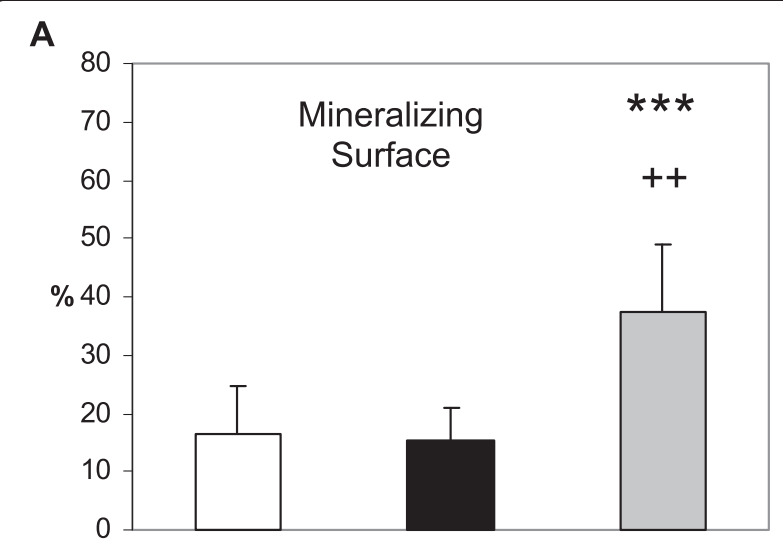

B

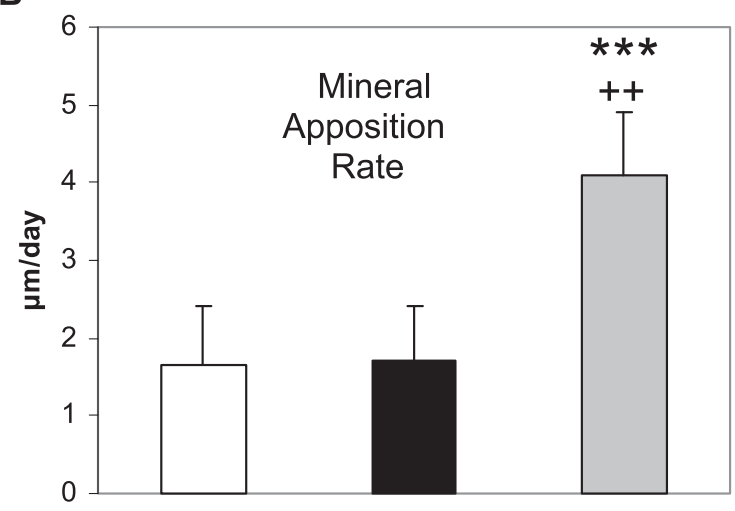

C

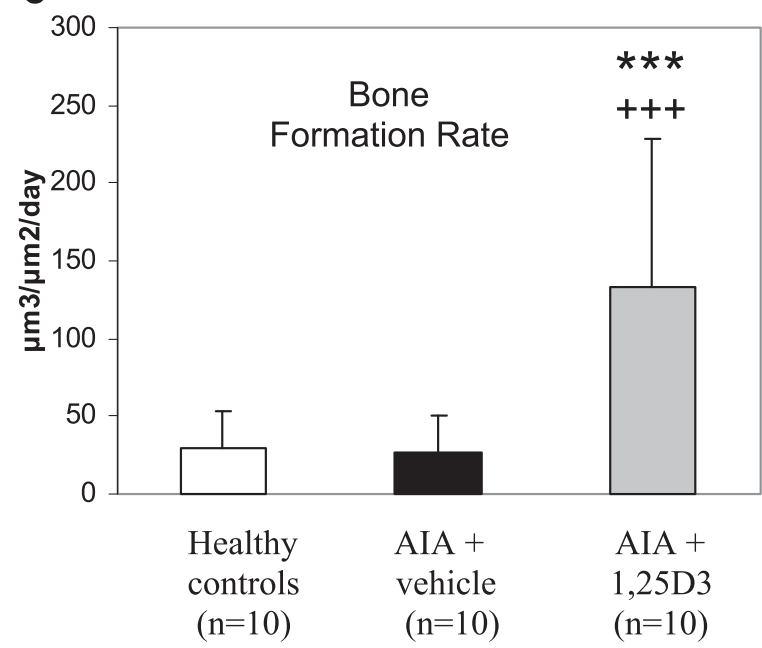

Figure 6 Influence of $1,25(\mathrm{OH})_{2} \mathrm{D}_{3}$ therapy on parameters of bone formation measured by tetracylin labeling (secondary spongiosa of the third lumbar vertebra) in AIA of the rat. Mineralizing surface (A), mineral apposition rate (B) and bone formation rate $(\mathbf{C})$ were unaffected by AIA. $1,25(\mathrm{OH})_{2} \mathrm{D}_{3}$ therapy resulted in a highly significant increase of mineralizing surface, mineral apposition rate and bone formation rate in comparison to both vehicle-treated AIA and healthy controls. ${ }^{* *} p<0.001$ vs. $\mathrm{AlA}+$ vehicle; $+++\mathrm{p}<0.001 ;++\mathrm{p}<0.01$ vs. healthy controls.
[52], a stimulation of mineralization by higher doses of $1,25(\mathrm{OH})_{2} \mathrm{D}_{3}$ has been demonstrated in vitro [53] and in vivo in rats at doses of 0.125 and $0.2 \mu \mathrm{g} / \mathrm{kg} /$ day $[54,55]$. In a recent study it has been shown, that suppression of interferon- $\beta$ mediated inhibitory effects on mineralization by $1,25(\mathrm{OH})_{2} \mathrm{D}_{3}$ may be critical for the stimulatory effects of $1,25(\mathrm{OH})_{2} \mathrm{D}_{3}$ on mineralization [56].

Interestingly, the resorption surface with osteoclasts was not increased by $1,25(\mathrm{OH})_{2} \mathrm{D}_{3}$ at the periarticular bone in our study and even significantly reduced at the axial bone. This result is surprising, because one of the most evident actions of $1,25(\mathrm{OH})_{2} \mathrm{D}_{3}$ on the bone is the induction of RANKL in osteoblasts resulting in a stimulation of osteoclastogenesis [35]. An indirect effect of $1,25(\mathrm{OH})_{2} \mathrm{D}_{3}$ on bone resorption mediated by reduction of inflammation resulting in a secondary decrease of bone resorption can be excluded as a cause for this observation, because $1,25(\mathrm{OH})_{2} \mathrm{D}_{3}$ has clearly no suppressive effect on inflammation in our treatment protocol. Despite the induction of RANKL, 1,25(OH) ${ }_{2} \mathrm{D}_{3}$-mediated inhibitory mechanisms on bone resorption have also been described. Thus, $1,25(\mathrm{OH})_{2} \mathrm{D}_{3}$ has been shown to interfere with RANK-mediated signaling by inhibiting the induction of c-Fos in a dosedependent manner via vitamin $\mathrm{D}$ receptor (VDR) in osteoclast precursor cells resulting in an inhibition of their differentiation into mature osteoclasts [57]. In addition, an inhibitory effect of $1,25(\mathrm{OH})_{2} \mathrm{D}_{3}$ on the differentiation of osteoclast precursors associated with a decreased RANK expression and an increased expression of the CCAAT enhancer-binding protein, an inhibitor of osteoclastogenesis on these cells has been proved in osteoclast precursors of normal peripheral blood and of synovial fluid of RA patients [58]. Furthermore, the RANKL/OPG ratio which is critical for the regulation of bone resorption is dependent on the differentiation state of the osteoblast [10,59]. For both human and mouse osteoblastic cells a decrease in RANKL/OPG ratio and in their osteoclastogenic potential, respectively, has been shown during the differentiation into mature osteoblasts [59-64]. The capacity of mineralisation is a feature of the mature osteoblast. Therefore, the finding of our study of a combination of an increase in mineralization with a reduction of osteoid-covered surface with osteoclasts is in accordance with the assumption, that $1,25(\mathrm{OH})_{2} \mathrm{D}_{3}$ treatment may induce the differentiation process of osteoblasts resulting in both increase in mineralization and a decrease in the osteoclastogenic potential of osteoblasts. Furthermore, a suppression of PTH secretion by 1,25 $(\mathrm{OH})_{2} \mathrm{D}_{3}$ or by $1,25(\mathrm{OH})_{2} \mathrm{D}_{3}$-induced slight hypercalcemia may also contribute to the reduction of resorption surface with osteoclasts. 
Because of the finding of reduced $1,25(\mathrm{OH})_{2} \mathrm{D}_{3}$ levels in both adjuvant arthritis of the rat $[27,28]$ and in RA patients with high disease activity [24] and with respect to the insignificant increase in periarticular osteoid volume in untreated AIA as a potential feature for slight osteomalacia, the question arises, if $1,25(\mathrm{OH})_{2} \mathrm{D}_{3}$ administration and effects in our study reflects in part a correction of an inflammation-associated $1,25(\mathrm{OH})_{2} \mathrm{D}_{3}$ deficiency. Although, serum levels of vitamin D metabolites were not measured in this study, this assumption is not probable, because $1,25(\mathrm{OH})_{2} \mathrm{D}_{3}$ serum levels in untreated AIA $(25.5 \pm 16.6 \mathrm{pg} / \mathrm{ml}, \mathrm{n}=7)$ have been found to be not reduced compared to healthy animals $(15.8 \pm$ $15.6 \mathrm{pg} / \mathrm{ml} ; \mathrm{n}=8$; n.s.) in an earlier investigation [65].

\section{Conclusions}

In summary, the results of our study indicate that the administration of active vitamin D hormone completely inhibited arthritis-induced bone loss by stimulation of mineralization at periarticular and axial bone and by inhibition of bone resorption at the axial bone despite missing effects on inflammation. The main cause of this beneficial effect of $1,25(\mathrm{OH})_{2} \mathrm{D}_{3}$ may be the induction of osteoblast differentiation resulting in both increasing mineralizing capacity of the single osteoblast and reduced osteoclastogenic potential of the mature osteoblast. Both an adequate vitamin D supply and the administration of active vitamin D metabolites could counteract and inhibit important mechanisms of bone loss in rheumatoid arthritis and should be used as an adjuvant therapeutic principle in this disease.

\section{Abbreviations \\ 1,25(OH $)_{2} \mathrm{D}_{3}: 1,25$-dihydroxyvitamin D3; AIA: Antigen-induced arthritis; CIA: Collagen-induced arthritis; mBSA: Methylated bovine serum albumin; OPG: Osteoprotegerin; PBS: Phosphate-buffered saline; RA: Rheumatoid arthritis; RANKL: Receptor of NFkappaB ligand; VDR: Vitamin D receptor.}

\section{Competing interests}

The authors declare that they have no competing interests.

\section{Authors' contributions}

PO and RB planned the design of the study. PO carried out the histomorphometric bone investigations and drafted the manuscript. PKP and RB carried out the investigation of clinical disease activity and of histopathology. GW and RB helped to draft the manuscript. All authors read and approved the final manuscript.

\section{Acknowledgements}

We thank Inge Schütz (Laboratory for Osteology, Department of Internal Medicine 3) for the preparation of undecalcified bone slices and Renate Stöckigt and Cornelia Hüttich (Institute of Pathology) for support at animal experiments and preparation of histological slides, respectively. This study did not receive any public or private funding.

\section{Author details}

'Department of Internal Medicine III, University Hospital of Jena, Erlanger Allee 101, 07740 Jena, Germany. ${ }^{2}$ Institute of Pathology, University Hospital of Jena, Ziegelmühlenweg 1, 07740 Jena, Germany.
Received: 21 May 2014 Accepted: 22 September 2014

Published: 14 October 2014

\section{References}

1. Gough AK, Lilley J, Eyre S, Holder RL, Emery P: Generalised bone loss in patients with early rheumatoid arthritis. Lancet 1994, 344:23-27.

2. Lodder MC, Haugeberg G, Lems WF, Uhlig T, Orstavik RE, Kostense PJ, Dijkmans BA, Kvien TK, Woolf AD, Oslo-Truro-Amsterdam (OSTRA) Collaborative Study: Radiographic damage associated with low bone mineral density and vertebral deformities in rheumatoid arthritis: the Oslo-Truro-Amsterdam (OSTRA) collaborative study. Arthritis Rheum 2003, 49:209-215.

3. Oelzner P, Schwabe A, Lehmann G, Eidner T, Franke S, Wolf G, Hein G: Significance of risk factors for osteoporosis is dependent on gender and menopause in rheumatoid arthritis. Rheumatol Int 2008, 28:1143-1150.

4. Kong YY, Feige U, Sarosi I, Bolon B, Tafuri A, Morony S, Capparelli C, Li J, Elliott R, McCabe S, Wong T, Campagnuolo G, Moran E, Bogoch ER, Van G, Nguyen LT, Ohashi PS, Lacey DL, Fish E, Boyle WJ, Penninger JM: Activated $T$ cells regulate bone loss and joint destruction in adjuvant arthritis through osteoprotegerin ligand. Nature 1999, 402:304-309.

5. Gravallese EM, Manning C, Tsay A, Naito A, Pan C, Amento E, Goldring SR: Synovial tissue in rheumatoid arthritis is a source of osteoclast differentiation factor. Arthritis Rheum 2000, 43:250-258.

6. Takayanagi $\mathrm{H}$, lizuka H, Juji T, Nakagawa T, Yamamoto A, Miyazaki T, Koshihara Y, Oda H, Nakamura K, Tanaka S: Involvement of receptor activator of nuclear factor kappaB ligand/osteoclast differentiation factor in osteoclastogenesis from synoviocytes in rheumatoid arthritis. Arthritis Rheum 2000, 43:259-269.

7. Rauner M, Sipos W, Pietschmann P: Osteoimmunology. Int Arch Allergy Immunol 2007, 143:31-48.

8. Schett G: Review: immune cells and mediators of inflammatory arthritis. Autoimmunity 2008, 41:224-229.

9. Karmakar S, Kay J, Gravallese EM: Bone damage in rheumatoid arthritis mechanistic insights and approaches to prevention. Rheum Dis Clin North Am 2010, 36:385-404.

10. Diarra D, Stolina M, Polzer K, Zwerina J, Ominsky MS, Dwyer D, Korb A, Smolen S, Hoffmann M, Scheinecker C, van der Heide D, Landewe R, Lacey D, Richards WG, Schett G: Dickkopf-1 is a master regulator of joint remodeling. Nat Med 2007, 13:156-163.

11. Polzer K, Diarra D, Zwerina J, Schett G: Inflammation and destruction of the joints - the wnt pathway. Joint Bone Spine 2008, 75:105-107.

12. Wruck CJ, Fragoulis A, Gurzynski A, Brandenburg LO, Kan YW, Chan K, Hassenpflug J, Freitag-Wolf S, Varoga D, Lippross S, Pufe T: Role of oxidative stress in rheumatoid arthritis: insights from the Nrf2-knockout mice. Ann Rheum Dis 2011, 70:844-850.

13. Atkins GJ, Andersn PH, Findlay DM, Welldon KJ, Vincen C, Zannettino ACW, O'Loughlin PD, Morris HA: Metabolism of vitamin D3 in osteoblasts: evidence for autocrine and paracrine activities of 1alpha, 25dihydroxyvitamn D3. Bone 2007, 40:1517-1528.

14. St Arnaud R: The direct role of vitamin D on bone homeostasis. Arch Biochem Biophys 2008, 473:225-230.

15. Anderson PH, Atkins GJ: The skeleton as an intracrine organ for vitamin $D$ metabolism. Mol Aspects Med 2008, 29:397-406.

16. Adams JS, Hewison M: Unexpected actions of vitamin D: new perspectives on the regulation of innate and adaptive immunity. Nat Clin Pract Endocrinol Metab 2008, 4:80-90.

17. Cutolo M, Straub RH: Insights into endocrine-immunological disturbances in autoimmunity and their impact to treatment. Arthritis Res Ther 2009, 11:218.

18. Hewison M: Vitamin $\mathrm{D}$ and the immune system: new perspectives on an old theme. Endocrinol Metab Clin North Am 2010, 39:365-379.

19. Bouvard B, Annweiler C, Salle A, Beauchet O, Chappard D, Audran M, Legrand E: Extraskeletal effects of vitamin D: facts, uncertainties, and controversies. Joint Bone Spine 2011, 78:10-16.

20. Zwerina K, Baum W, Axmann R, Ruiz Heiland G, Distler JH, Smolen J, Hayer S, Zwerina J, Schett G: Vitamin D receptor regulates TNF-mediated arthritis. Ann Rheum Dis 2011, 70:1122-1129.

21. van Hamburg JP, Asmawidjaja PS, Davelaar N, Mus AMC, Cornelissen F, van Leeuwen JPTM, Hazes JMW, Dolhain RJEM, Bakx PAGM, Colin EM, Lubberts E: TNF blockade requires 1,25(OH)2D3 to control human Th17-mediated synovial inflammation. Ann Rheum Dis 2012, 71:606-612. 
22. Zhang Y, Leung DYM, Richers BN, Liu Y, Remigio LK, Riches DW, Goleva E: Vitamin D inhibits monocyte/macrophage proinflammatory cytokine production by targeting MAPK phosphatase-1. J Immunol 2012, 188:2127-2135.

23. Cutolo M: Further emergent evidence for the vitamin $D$ endocrine system involvement in autoimmune rheumatic disease risk and prognosis. Ann Rheum Dis 2013, 72:473-475.

24. Oelzner P, Müller A, Deschner F, Hüller M, Abendroth K, Hein G, Stein G: Relationship between disease activity and serum levels of vitamin $D$ metabolites and PTH in rheumatoid arthritis. Calcif Tissue Int 1998, 62:193-198.

25. Patel S, Farragher T, Berry J, Bunn D, Silman A, Symmons D: Association between serum vitamin $D$ metabolite levels and disease activity in patients with early inflammatory polyarthritis. Arthritis Rheum 2007, 56:2143-2149.

26. Binderup L: Bone changes in rats with adjuvant arthritis: treatment with 1-alpha-hydroxcholecalciferol. Acta Pharmacol Toxicol (Copenh) 1986, 59:228-235

27. Langman CB, Ford KK, Pachman LM, Glorieux F: Vitamin D metabolism in rats with adjuvant-induced arthritis. J Bone Miner Res 1990, 5:905-913.

28. Sergeev IN, Spirichev VB, Bogoslovskii NA, Korsova TL, Morozova NA, Poznanskaja AA: The vitamin $D$ enocrine system and bone tissue mineral metabolism in rats with adjuvant arthritis: the effect of 1,25dihydroxyvitamin D3. Biull Eksp Biol Med 1992, 114:510-512.

29. Boissier MC, Chiocchia G, Fournier C: Combination of cyclosporine A and calcitriol in the treatment of adjuvant arthritis. J Rheumatol 1992, 19:754-757

30. Tsuji M, Fujii K, Nakano T, Nishii Y: 1a-hydroxyvitamin D inhibits type II collagen-induced arthritis in rats. FEBS Lett 1994, 337:248-250.

31. Kitamura A: Study of the effects of a new vitamin D3 derivative on type II collagen-induced arthritis in an experimental rat model of rheumatoid arthritis. Nihon Seikeigeka Gakkai Zasshi 1994, 68:1068-1080.

32. Cantorna MT, Hayes CE, DeLuca HF: 1,25-Dihydroxycholecalciferol inhibits the progression of arthritis in murine models of human arthritis. J Nutr 1998, 128:68-72.

33. Larsson $P$, Mattsson $L$, Klareskog $L$, Johnsson C: A vitamin D analogue (MC 1288) has immunomodulatory properties and suppresses collagen-induced arthritis (CIA) without causing hypercalcaemia. Clin Exp Immunol 1998, 114:277-283.

34. Moghaddami M, Mayrhofer G, Anderson PH, Morris HA, van der Hoek M, Cleland LG: Efficacy and mechanisms of action of vitamin D in experimental polyarthritis. Immunol Cell Biol 2012, 90:168-177.

35. Nakashima T, Kobayashi Y, Yamasaki S, Kawakami A, Equchi K, Sasaki H, Sakai H: Protein expression and functional difference of membrane-bound and soluble receptor activator of NF-kappaB ligand: modulation of the expression by osteotropic factors and cytokines. Biochem Biophys Res Commun 2000, 275:768-775.

36. Pohlers D, Nissler K, Frey O, Simon J, Petrow PK, Kinne RW, Bräuer R: Anti-CD4 monoclonal antibody treatment in acute and early chronic antigen-induced arthritis influence T helper cell activation. Clin Exp Immunol 2004, 135:409-415.

37. Frey O, Petrow PK, Gajda M, Siegmund K, Huehn J, Scheffold A, Hamann A, Radbruch A, Bräuer R: The role of regulatory T cells in antigen-induced arthritis: aggravation of arthritis after depletion and amelioration after transfer of CD4 + CD25+ T cells. Arthritis Res Ther 2005, 7:291-301.

38. Vieth R, Milojevic S, Peltkova V: Improved cholecalciferol nutrition in rats is noncalcemic, suppresses parathyroid hormone and increases responsiveness to 1,25-dihydroxycholecalciferol. J Nutr 2000, 130:578-584

39. Zimmermann M: Ethical guidelines for investigations of experimental pain in conscious animals. Pain 1983, 16:109-110.

40. Bräuer R, Kette H, Henzgen S, Thoss K: Influence of cyclosporin A on cytokine levels in synovial fluid and serum of rats with antigen-induced arthritis. Agents Actions 1994, 41:96-98.

41. Delling G: Endocrine Bone Diseases. Stuttgart: Gustav Fischer; 1975

42. Neumann T, Oelzner P, Petrow PK, Thoss K, Hein G, Stein G: Osteoprotegerin reduces the loss of periarticular bone mass in primary and secondary spongiosa but does not influence inflammation in rat antigen-induced arthritis. Inflamm Res 2006, 55:32-39.

43. Murakami H, Nakamura T, Tsurukami H, Abe M, Barbier A, Suzuki K: Effects of tiludronate on bone mass, structure and turnover at the epiphyseal, primary and secondary spongiosa in the proximal tibia of growing rats after sciatic neurectomy. J Bone Miner Res 1994, 9:1355-1364.

44. Ma YF, Jee WS, Ke HZ, Lin BY, Liang XG, Li M, Yamamoto N: Human parathyroid hormone (1-38) restores cancellous bone to the immobilized, osteopenic proximal tibial metaphysis in rats. J Bone Miner Res 1995, 10:496-505.

45. Malluche HH, Faugere MC: Atlas of Mineralized Bone Histology. Basel München - Paris - London - New York - New Dehli - Singapore - Tokyo Sidney: Karger; 1986.

46. Parfitt AM, Drezner MK, Glorieux FH, Kanis JA, Malluche $H$, Meunier PJ, Ott SM, Recker RR: Bone histomorphometry: standardization of nomenclature symbols and units: report of the ASBMR Histomorphometry Nomenclature Committee. J Bone Miner Res 1987, 2:595-610.

47. Aota S, Nakamura T, Suzuki K, Tanaka Y, Okazaki Y, Segawa Y, Miura M, Kikuchi S: Effects of indomethazin administration on bone turnover and bone mass in adjuvant arthritis in rats. Calcif Tissue Int 1996, 59:385-391.

48. Einspruch EL: An Introductory Guide to SPSS for Windows. Thousand Oaks London - New Delhi: Sage Publications Inc; 2005.

49. Gardiner EM, Baldock PA, Thomas GP, Sims NA, Henderson NK, Hollis B, Whit $C P$, Sunn KL, Morrison NA, Walsh WR, Eisman JA: Increased formation and decreased resorption of bone in mice with elevated vitamin $D$ receptor immature cells of the osteoblastic lineage. FASEB J 2000, 14:1908-1916

50. Kveiborg M, Rattan SI, Clark BF, Eriksen EF, Kassem M: Treatment with 1,25dihydroxyvitamin D3 reduces impairment of human osteoblast functions during cellular aging in culture. J Cell Physiol 2001, 186:298-306.

51. Paredes R, Arriagada G, Cruzat F, Villagra A, Olate J, Zaidi K, van Wijnen A, Lian JB, Stein GS, Stein JL, Montecino M: Bone specific transcription factor Runx2 interacts with the 1alpha,25-dihydroxyvitamin D3 receptor to up-regulate rat osteocalcin gene expression in osteoblastic cells. Mol Cell Biol 2004, 24:8847-8861.

52. Gunness-Hey M, Gera I, Fonseca J, Raisz LG, Hock JM: 1,25 dihydroxyvitamin D3 alone or in combination with parathyroid hormone does not increase bone mass in young rats. Calcif Tissue Int 1988, 43:84-88.

53. Matsumoto T, Igarashi $C$, Takeuchi $Y$, Harada S, Kikuchi T, Yamato H, Ogata E: Stimulation by 1,25-dihydroxyvitamin D3 of in vitro mineralization induced by osteoblast -like MC3T3-E1 cells. Bone 1991, 12:27-32.

54. Lempert UG, Minne HW, Albrecht B, Scharla SH, Matthes F, Ziegler R: 1,25-Dihydroxyvitamin D3 prevents the decrease of bone mineral appositional rate in rats with inflammation-mediated osteopenia (IMO). Bone Miner 1989, 7:149-158.

55. Erben RG, Scutt AM, Miao D, Kollenkirchen U, Haberey M: Short-term treatment of rats with high dose 1,25-dihydroxyvitamin D3 stimulates bone formation and increases the number of osteoblast precursor cells in bone marrow. Endocrinology 1997, 138:4629-4635.

56. Woeckel V, Koedam M, van de Peppel J, Chiba H, van der Eerden B, vam Leeuwen J: Evidence of vitamin $D$ and interferon- $\beta$ cross-talk in human osteoblasts with 1a25-dihydroxyvitamin D3 being dominant over interferon- $ß$ in stimulating mineralization. J Cell Physiol 2012, 227:32583266.

57. Takasu H: Anti-osteoclastogenic action of active vitamin D. Nutr Rev 2008, 66(Suppl 2):113-115.

58. Ji JD, Kim TH, Lee B, Jun JB, Yoo DH, Choi SJ, Lee YH, Kim Y, Sohn J, Song GG: 1,25-dihydroxyvitamin D3 inhibits osteoclast differentiation from CD14+ osteoclast precursors of normal peripheral blood and rheumatoid arthritis synovial fluid. Ann Rheum Dis 2011, 70(Suppl 3):354.

59. Atkins GJ, Kostakis P, Pan B, Farrugia A, Gronthos S, Evdokiou A, Harrison K, Findlay DM, Zannettino AC: RANKL expression is related to the differentiation state of human osteoblasts. J Bone Miner Res 2003, 18:1088-1098.

60. Thomas GP, Baker SU, Eisman JA, Gardiner EM: Changing RANKL/OPG mRNA expression in differentiating murine primary osteoblasts. J Endocrinol 2001, 170:451-460.

61. Giner M, Montoya MJ, Vazquez MA, Rios MJ, Moruno R, Miranda MJ, Perez-Cano R: Modifying RANKL/OPG mRNA expression in differentiating and growing human primary osteoblasts. Horm Metab Res 2008, 40:869-874.

62. Rauner M, Sipos W, Goettsch C, Wutzl A, Foisner R, Pietschmann P, Hofbauer LC: Inhibition of lamin A/C attenuates osteoblast differentiation and enhances RANKL-dependent osteoclastogenesis. J Bone Miner Res 2009, 24:78-86.

63. Id Boufker H, Lagneaux L, Najar M, Piccart M, Ghanem G, Body JJ, Journe F: The Src inhibitor dasatinib accelerates the differentiation of human 
bone marrow-derived mesenchymal stromal cells into osteoblasts. BMC Cancer 2010, 10:298. doi:10.1186/1471-2407-10-298.

64. Li H, Jiang X, Delaney J, Franceschetti T, Bilic-Curcic I, Kalinovsky J, Lorenzo $J A$, Rowe DW, Kalajzic I: Immature osteoblast lineage cells increase osteoclastogenesis in osteogenesis imperfecta murine. Am J Pathol 2010, 176:2405-2413.

65. Oelzner $P$, Bräuer R, Henzgen $S$, Thoss $K$, Wünsche B, Hersmann G, Abendroth K, Kinne RW: Periarticular bone alterations in chronic antigen-induced arthritis: free and liposome-encapsulated clodronate prevent loss of bone mass in the secondary spongiosa. Clin Immunol 1999, 90:79-88.

doi:10.1186/1471-2474-15-345

Cite this article as: Oelzner et al:: 1,25-Dihydroxyvitamin D3 prevents bone loss of the secondary spongiosa in arthritic rats by an increase of bone formation and mineralization and inhibition of bone resorption. BMC Musculoskeletal Disorders 2014 15:345.

\section{Submit your next manuscript to BioMed Central and take full advantage of:}

- Convenient online submission

- Thorough peer review

- No space constraints or color figure charges

- Immediate publication on acceptance

- Inclusion in PubMed, CAS, Scopus and Google Scholar

- Research which is freely available for redistribution 